the inclination of the axis of rotation of the moon to the plane of the orbit has undergone important variations.

In order to understand the mechanism of the depressions which have caused the seas, the phenomena must be seen at different stages of advancement, and for this purpose it is necessary to study in detail how the transition between the great southern cap, which is mountainous, and the plains of the equatorial region have been effected. This passage may be studied on Plate XIV., of which nearly half, occupied by the Mer des Nuages, indicates numerous obliterated or submerged formations. The traces of the most ancient depressions have naturally disappeared by the overflowing of lava, but the more modern depressions on a dry and resisting crust, often allow their contour and size to be recognised. Some of these are connected to the central portions of the seas, leaving a great exterior band joining the mountains, which serve at the same time as limit and fulcrum. The two portions of crust thus disjointed have only been able to acquire a relative movement in a vertical direction. The part which remained immovable constitutes, in relation to the other, a sort of raised terrace. Thus must be interpreted the celebrated formation known by the name of "The Straight Wall." As the same map shows it us a little distance off, the rupture can also be accompanied by a tangential slip. It appear then like a large crevice, similar to those we saw appearing to the east of Hesiod. These fissures may be connected with large portions of the crust, may even divide chains of hills, and their form, generally rectilinear, seems independent of all the small inequalities of the surface.

It can easily be understood that such crevices rarely acquire dimensions large enough to be visible from our earth. Further, it is only near the boundaries of the seas that they have a chance of remaining open. In the central parts, the submersion of the surface has made every vestige disappear. The zones near the limb are also, by reason of the variations of the interior pressure, subject to encroachments of lava. But these inundations, which are not so frequent, are not uniformly distributed. They give rise to solid accumulations along the crevices from which they issue, and they take the form of swollen nerves. Two of these net-works can be studied in the present--and third-part; one stretching to the west of Bouillaud (Plate XIV.), the other between Landsberg and Wichmann (Plate XV.). In this last system we see a large region composed alternately of hollows and hills, as if to enable us to note the change.

The evidence of volcanic action appears here with an amplitude, a clearness, which leaves little to be desired. We have had to content ourselves with a somewhat smaller enlargemen in order to comprise in two consecutive pages (Plates XV. and XVI.) the largest portions of these brilliant aureoles, that are seen shining round certain walled plains, as Lalande, Kepler, or Copernicus. It seems to us that the comparison of these two pages is very suggestive. One is convinced by it that the diverging trails, becoming invisible by a very oblique illumination, cannot be interpreted as inequalities of the surface. Inter secting valleys and mountains without becoming fainter or deviating from their course, they cannot have been produced by subterranean or superficial means. An atmosphere agitated by variable currents seems to be the only cause which can explain the diffusion of tracks to such distances. This hypothesis further agrees with what we know of the extreme tenuity of volcanic dusts, with their capability of remaining for a long time in suspension in very thin air. It is strengthened by the fact of the existence of a relatively dark corona round the principal centres of luminosity. It is possible that in a certain zone round the more recent craters, like the region in the neighbourhood of terrestrial volcanoes, the largest projectiles, the streams of lava have got mixed in the deposits of cinders, and have not allowed them to remain clearly visible near these orifices.

Without misunderstanding the evident unity of origin of these tracks of a same system, one might be surprised to see their direction, their size, and their brightness sometimes undergoing sudden changes without clear relation to the distance of the central crater. Two disturbing causes seem to interfere: one is the meeting of high mountains, capable of dividing the atmospheric currents, of causing downfalls, and abundant condensation. The other, more frequent and more efficient, is the presence of hollow basins, still liquid at the time the downfalls of cinders took place, useless in consequence of receiving or keeping superficial deposits. The tracks, therefore, behave in the plains like a very sensitive reagent, being able to disclose by a recrudescence of brightness the smallest unevenness of the surface, and, by a sudden weakening, the slowly solidified lagoons. The comparative examination of a similar region, described in the Plates XV. and XVI. under contrary conditions, furnished numerous facts in support of this idea.

Are some of these deep basins still imperfectly dry, and will their physical state consequently be changed by a prolonged exposure to the solar rays? The green and red tints that are seen in the neighbourhood of the terminator, in the interior of some walled plains, make one think that this is so. The eye being more sensitive in the appreciation of tints, photography has the advantage of the impartial registering of relative luminous intensities. It has, without contradiction, the right to bring its evidence into the question. Plate XVII., which represents a region where the sun is setting, must be compared from this point of view with Plate I., where the sun is rising on the same parts. We find these dark spots of even tone, which in the interval have obviously modified their tints relatively to the neighbouring plateaus. The reality of this change has been confirmed by the examination of a series of clichés arranged in intermediate phases.

Below we sum up the principal ideas which this third part suggests or confirms, and which one will find developed in the following pages containing the description of the different plates. They are :-

(I) The explanation of the relative stability and the mountainous character of the polar caps.

(2) The extension of these same characters to every region which form the apparent limb.

(3) The geometric reason of the approximate coincidence that one sees between the curves of equal illumination on the disc and meridians.

(4) The origin of the abnormal recrudescence of luminosity which is shown at the apparent limb in contradiction to calculation.

(5) The difference of constitution of the two poles seems to indicate that the axis of rotation has undergone great displacements in the interior of the planet.

(6) The cause of the predominance of the seas in equatorial regions.

(7) The interpretation of the different tints that are apparent in the tracks; the use of the dark spots to recognise, amongst the sunken basins of the lunar surface, those which have been the last to solidify.

Results of equal interest can apparently be deduced from the fourth and fifth parts, the materials of which we have in hand. We hope the studious public will not have very long to wait for the rest of this work, for it has indeed been good enough to see in the two first parts an appreciable addition to our selenographic knowledge. However, we do not doubt that it is possible to do more, and also better; for if we think we have brought the methods of reproduction to the desired degree of perfection, it is not the case in the execution of direct photographs, which remains, by reason of the habitual movement of the images, a very difficult operation. A single cliché, available for enlarging, represents practically for us the only result of several months' work, and in certain phases our best proofs betray, in a very apparent way, the unsteadiness of the atmosphere.

\section{OYSTERS AND DISEASE.}

$T H I S$ research was commenced three years ago, and has been carried on intermittently in the intervals of other work.

Preliminary reports on some of our results have been laid before the British Association at the Ipswich, Liverpool, Toronto, and Bristol meetings, and a short paper on one section of the subject was communicated to the Royal Society and printed in the Proceedings last year. In the present paper we give a full account, with illustrations, of the detailed evidence upon which our various conclusions are based. The following is a brief statement of the more important results given in the paper :-

(I) Although our primary object was to study the oyster under unhealthy conditions, in order to elucidate its supposed connection with infective disease, we found it necessary to study

1 "Observations upon the Normal and Pathological Histology and Bacteriology of the Oyster." By Profs. W. A. Herdman, F.R.S., and Rubert Boyce. (Abstract of a paper read before the Royal Society, January rg.) 
in minute detail the histology of certain parts of the body, especially the gills and mantle lobes, the alimentary canal and liver. We give figures and descriptions of these structures in both normal and abnormal conditions.

(2) We have also worked out the distribution and probable function of a miuute muscle, which we believe to be the modified representative of the protractor pedis muscle of some other molluscs.

(3) A diseased condition we found in certain American oysters very soon brought us into contact with the vexed question of the "greening" of oysters, and one of the first results we arrived at was that there are several distinct kinds of greenness in oysters. Some of them, such as the green Marennes oysters, and those of some rivers on the Essex coast are healthy; while others, such as some Falmouth oysters, containing copper, and some American oysters re-bedded on our coast, and which have the pale-green "leucocytosis" described in our former paper to the Royal Society, are not in a healthy state.

(4) Some forms of greenness (e.g. the leucocytosis) are certainly associated with the presence of a greatly increased amount of copper in the oyster, while other forms of greenness (e.g. that of the Marennes oysters) have no connection with copper, but depend upon the presence of a special pigment, "marennin."

We are able, in the main, to support Ray Lankester in his observations on Marennes oysters ; but we regard the wandering amœboid granular cells on the surface of the gills as leucocytes which have escaped from the blood spaces, and have probably assumed a phagocytic function.

(5) We see no reason to think that any iron which may be associated with any marennin in the gills, \&c., is taken in through the surface epithelium of the gill and palps, but regard it, like the rest of the iron in the body, as a product of ordinary digestion and absorption in the alimentary canal and liver.

(6) We do not find that there is any excessive amount of iron in the green Marennes oyster compared with the colourless oyster, nor do the green parts (gills, palp, \&c.) of the Marennes oyster contain either absolutely or relatively to the colourless parts (mantle, \&c.) more iron than colourless oysters. We therefore conclude that there is no connection between the green colour of the "Huîtres de Marennes" and the iron they may contain.

(7) On the other hand, we do find by quantitative analysis that there is more copper in the green American oyster than in the colourless one; and more proportionately in the greener parts than in those that are less green. We therefore conclude that their green colour is due to copper. We also find a greater quantity of iron in those green American oysters than in the colourless ; but this excess is, proportionately, considerably less than that of the copper.

(8) In the Falmouth oysters, containing an excessive amount of copper, we find that much of the copper is certainly mechanically attached to the surface of the body, and is in a form insoluble in water, probably as a basic carbonate. In addition to this, however, the Falmouth oyster may contain a much larger amount of copper in its tissues than does the normal colourless oyster. In these Falmouth oysters the cause of the green colour may be the same as in the green American oyster.

(9) By treating sections of diseased American oysters under the microscope with potassium ferrocyanide and various other reagents, we find that the copper reactions correspond in distribution with the green coloration; and we find, moreover from these micro-chemical observations that the copper is situated in the blood-cells or leucocytes, which are greatly increased in number. This condition may be described as a green leucocytosis, in which copper in notable amount is stored up in the leucocytes.

(IO) We find that an aqueous solution of pure hæmatoxylin is an extremely delicate test for copper, just as Macallum found it to be for iron.

(II) Experiments in feeding oysters with weak solutions of various copper and iron salts gave no definite results, certainly no clear evidence of any absorption of the metals accompanied by "greening."

(12) Although we did not find the Bacillus typhosus in any oysters obtained from the sea or from the markets, yet in our experimental oysters inoculated with typhoid we were able to recover the organism from the body of the oyster up to the

$$
\text { Nก. I } 526 \text {, vOL. 59] }
$$

tenth day. We show that the typhoid bacillus does not increase in the body or in the tissues of the oyster, and our figures indicate that the bacilli perish in the intestine.

(I3) Our experiments showed that sea-water was inimical to the growth of the typhoid bacilli. Although their presence was demonstrated in one case on the twenty-first day after addition to the water, still there appeared to be no initial or subsequent multiplication of the bacilli.

(14) In our experiments in washing infected oysters in a stream of clean sea-water the results were definite and uniform; there was a great diminution or total disappearance of the typhoid bacilli in from one to seven days.

(15) The colon group of bacilli is frequently found in shellfish as sold in towns, and especially in the oyster; but we have no evidence that it occurs in mollusca living in pure sea-water. The natural inference that the presence of the colon bacillus invariably indicates sewage contamination must, however, not be considered established without further investigation.

(16) The colon group may be separated into two divisions: (I) those giving the typical reactions of the colon bacillus, and (2) those giving corresponding negative reactions, and so approaching the typhoid type; but in no case was an organism giving all the reactions of the $B$. typhosus isolated. It ought to be remembered, however, that our samples of oysters, although of various kinds and from different sources, were in no case, so far as we are aware, derived from a bed known to be contaminated or suspected of typhoid.

(I7) We have shown also the frequent occurrence, in various shell-fish from the shops, of anaerrobic spore-bearing bacilli giving the characteristics of the $B$. enteritidss sporogenes recently described by Klein.

(18) As the result of our work, we make certain recommendations as to the sanitary regulation and registration of the oyster beds, and as to quarantine for oysters imported from abroad.

\section{THE DUKE OF DEVONSHIRE ON SECONDARY EDUCATION.}

THE Duke of Devonshire opened the new building of the Municipal Technical College at Derby on Thursday last ; and in the course of an address delivered at a luncheon given by the Mayor of Derby on that occasion, he is reported by the Times to have made the following remarks upon the value of scientific instruction and the reform of secondary education.

The inhabitants of Derby had not up to the present time enjoyed all the advantages in obtaining a scientific education which would have been so useful to a town possessing so many, so large, and so varied industries. But science instruction in Derby was now, he trusted, entering upon a new course, and he had little doubt that the instruction in science which would be carried on in that building would be as thorough as that which had hitherto been accomplished in the art school. Though they had made a great step in the erection and completion of these buildings, a great deal still remained to be done. The erection of the most complete buildings and the calling of them a college would not be of much use unless at the same time they were able to obtain a competent staff of teachers. That, he had no doubt, had already been done; but, even when they had done that, they must remember that independent classes and courses of lectures, useful as they might be in enabling students to acquire certain branches of knowledge which would be of use to them in future years, would not, unless they were organised on the principles to some extent which prevailed in our older schools and colleges, provide that intellectual training and that mental discipline which was more valuable than any acquired knowledge.

He and many with him, much more able than himself, had during a good many years advocated the absolute national necessity of giving to our people a better technical, artistic, and scientific training. He had urged it in the interests of the maintenance of our industrial supremacy and in the interests of our industrial and commercial existence. The necessity for placing these means of technical instruction within the reach of our people was now universally admitted. There was a movement in this direction in every part of the country, and, in addition to what had hitherto been known as the technical education movement, there was an equally strong desire for the addition of what was termed commercial education. But what 